\title{
Increase in hepatitis A in tourists from Denmark, England, Germany, the Netherlands, Norway and Sweden returning from Egypt, November 2012 to March 2013
}

E MacDonald (emily.macdonald@fhi.no)1,2, A Steens ${ }^{1,2}$, K Stene-Johansen ${ }^{1}$, S Gillesberg Lassen 3, S E Midgley ${ }^{4}$, J Lawrence ${ }^{5}$,

J Crofts 5 , S L Ngui ${ }^{5}$, K Balogun 5 , C Frank ${ }^{6}$, M Faber ${ }^{6}$, M Gertler ${ }^{6,7}$, L Verhoef ${ }^{8}$, M Koopmans ${ }^{8}$, J Sane ${ }^{2,8}$, W van Pelt ${ }^{8}$, L Sundqvist ${ }^{9}$, L Vold ${ }^{1}$

1. Norwegian Institute of Public Health, Oslo, Norway

2. European Programme for Intervention Epidemiology Training (EPIET), European Centre for Disease Prevention and Control $(E C D C)$, Stockholm, Sweden

3. Department of Infectious Disease Epidemiology, Statens Serum Institut, Copenhagen, Denmark

4. Department of Microbiological Diagnostics and Virology, Statens Serum Institut, Copenhagen, Denmark

5. Public Health England, London, England

6. Robert Koch Institute, Berlin, Germany

7. Postgraduate Training for Applied Epidemiology, Germany

8. National Institute for Public Health and the Environment (RIVM), Netherlands

9. Swedish Institute for Communicable Disease Control, Stockholm, Sweden

Citation style for this article:

MacDonald E, Steens A, Stene-Johansen K, Gillesberg Lassen S, Midgley SE, Lawrence J, Crofts J, Ngui SL, Balogun K, Frank C, Faber M, Gertler M, Verhoef L, Koopmans M, Sane J, van Pelt W, Sundqvist L, Vold L. Increase in hepatitis A in tourists from Denmark, England, Germany, the Netherlands, Norway and Sweden returning from Egypt, November 2012 to March 2013. Euro Surveill. 2013;18(17):pii=20468. Available online: http://www.eurosurveillance.org/ViewArticle. aspx?Articleld $=20468$

Since November 2012, there has been an increase in reported cases of hepatitis $A$ in tourists returning from Egypt in several European countries. As of 24 April, 80 HAV cases in travellers with symptom onset after 1 November 2012 visiting different areas in Egypt have been reported. Four cases from Norway, six cases from the Netherlands and five cases from England share an identical hepatitis A viral RNA sequence. This increase in cases suggests that vaccination recommendations for travellers to hepatitis A endemic countries should be reinforced.

\section{The alert}

Since January 2013, six hepatitis A cases with travel history to Egypt during the incubation period (2-6 weeks after infection) were reported to the Norwegian Surveillance System for Communicable Diseases (MSIS). Typically, a single case of hepatitis A with travel history to Egypt is reported in Norway annually. Four of the six cases were genotyped and were found to be infected with the same genotype $1 B$ hepatitis $A$ virus (HAV)-strain. On 15 April 2013, the Norwegian Institute of Public Health posted an urgent inquiry on the Epidemic Intelligence Information System (EPIS) platform asking if any other European countries had observed an increase in HAV with travel history to Egypt in the same period. The genome sequence ( $\mathrm{N}$-terminal $V P_{1}$ and $V_{1} / P_{2} A$ ) shared by the four Norwegian cases was also provided at this time. Initially, four countries (Denmark, Germany, Netherlands and Sweden) responded that they had all observed an increased number of hepatitis A patients with travel history to Egypt. On 19 April 2013, an alert was also sent through the European Commission Early Warning and Response System (EWRS). Subsequently, an increase in HAV cases in tourists returning to England was also reported. A multi-national investigation has been initiated in order to identify European Union/ European Economic Area (EU/EEA) countries with reported increases in HAV among travellers to Egypt, compare travel history among cases, and potentially identify any common exposures among travellers originating from different countries.

\section{Background}

The incidence of HAV in European countries has decreased from 15.1 in 1996 to 3.9 per 100,000 population in 2006, attributable to improved sanitary and living conditions $[1,2]$. However, the reduction in circulation of HAV has led to an increase of susceptible individuals, resulting in several outbreaks in recent years, notably among European tourists visiting Egypt [3-6]. In Egypt, the burden of disease due to HAV is one of the highest in the world, with most HAV strains belonging to genotypes $1 \mathrm{~A}$ and $1 \mathrm{~B}$. Recent studies of the presence of HAV in sewage and in the population have shown that the virus circulates widely in Egypt [7]. Egypt is a popular destination for travellers from many European countries (Table 1) [8-12]. HAV vaccination is generally recommended for all travellers to Egypt, although funding the vaccination for tourists or including the vaccine as part of the national vaccination plan is uncommon. 
TABLE 1

Information on travel to Egypt for Denmark, England, Germany, the Netherlands, Norway and Sweden

\begin{tabular}{|l|l|}
\hline Country & Information on travel to Egypt \\
\hline Denmark & Unavailable \\
\hline England & $\begin{array}{l}\text { The estimated number of annual visits to Egypt } \\
\text { by residents of England (on average between } \\
2008 \text { and 2012) is approximately 540,000. } \\
\text { However, the number of visits to Egypt has been } \\
\text { decreasing over the last four years (367,793 in } \\
\text { 2012 compared to 673,227 in 2009). }\end{array}$ \\
\hline Germany & $\begin{array}{l}\text { According to the National Statistics Office } \\
\text { in Germany, 1,275,872 persons travelled by } \\
\text { air between Germany and Egypt from March } \\
\text { 2012 through February 2013 (most recent data } \\
\text { available). }\end{array}$ \\
\hline Netherlands & $\begin{array}{l}\text { Data from the Central Bureau of Statistics in the } \\
\text { Netherlands indicates that the number of visits } \\
\text { to Egypt has remained relatively stable over } \\
\text { the last five years, with approximately } 1 \%, \text { or } \\
\text { approximately 241,00o, of all documented travels } \\
\text { going to Egypt annually. }\end{array}$ \\
\hline Norway & $\begin{array}{l}\text { The Norwegian Embassy in Egypt estimates that } \\
\text { approximately 40,00o Norwegians visit Egypt } \\
\text { annually. }\end{array}$ \\
\hline $\begin{array}{l}\text { According to the Swedish Travel and Tourist } \\
\text { database an average number of 170,236 persons } \\
\text { travelled annually to Egypt from Sweden during } \\
\text { the last four years. The number for 2012 was } \\
\text { 178,362 persons. }\end{array}$ \\
\hline Sweden
\end{tabular}

Hepatitis A cases are mandatorily notifiable in all EU/ EEA countries. In Denmark, Germany, the Netherlands, Norway and Sweden, age, sex, vaccination status and location of travel is submitted as part of the notification. In England the same information is recorded at notification with the exception of vaccination status and location of travel which is collected as part of local public health surveillance. In Denmark, Statens Serum Institut performs sequencing for surveillance purposes of all IgM positive samples received from local diagnostic laboratories. At the Norwegian and Dutch Institutes of Public Health samples are analysed for sequence comparison, on request, such as in suspected outbreaks. In Sweden and Germany, genotyping is not done routinely. In England, HAV IgM positive serum samples are genotyped and sequenced as part of the enhanced surveillance programme.

Case definition for the outbreak investigation

A probable case is defined as a symptomatic person positive for HAV IgM with onset of symptoms or testing date (if date of symptom onset is unavailable) after 1 November 2012 and with travel history to Egypt two to six weeks before onset of symptoms/date of testing (if date of symptom onset is unavailable) and with no other known hepatitis A exposure.

A confirmed case is defined as a probable case with RNA sequence matching the Norwegian outbreak sequence. HAV cases are excluded if they are a different genotype or have a different sequence to the outbreak strain. Probable cases that are found to have a different genotype or a different sequence are being excluded at this time.

\section{Description of cases}

As of 24 April, 80 HAV cases in travellers with symptom onset after 1 November 2012 visiting different areas in Egypt have been reported (Table 2). Overall, $46 \%$ of cases are male, and the ages of cases range from three to 76 years (Table 3). Onset of symptoms of HAV cases ranged from week 44 of 2012 (29 October to 4 November) to Week 15 of 2013 (8 April to 14 April) (Figure). Cases occurred in several waves, with a peak in Week 6 (4 February to 10 February). Cases from England, the Netherlands and Norway sharing the outbreak strain are clustered between Week 5 and Week 13. Cases travelled primarily to Sharm-El-Sheik and Hurghada (Table 4), with cases linked by genotyping reporting travel history to both Sharm-El-Sheik and Hurghada.

TABLE 2

Hepatitis A cases in travellers to Egypt from Denmark, England, Germany, the Netherlands, Norway and Sweden with symptom onset date ${ }^{\mathrm{a}}$ after 01 November 2012 as of 24 April $2013(\mathrm{n}=80)$

\begin{tabular}{|c|c|c|c|c|}
\hline Country of origin & $\begin{array}{l}\text { Total number of } \\
\text { outbreak cases }\end{array}$ & $\begin{array}{c}\text { Number of } \\
\text { probable cases }\end{array}$ & $\begin{array}{c}\text { Number of } \\
\text { confirmed cases }\end{array}$ & $\begin{array}{c}\text { Mean number of } \\
\text { cases in the same period } \\
2007-2012\end{array}$ \\
\hline Denmark & 7 & 7 & 0 & 1.2 \\
\hline England & 11 & 6 & 5 & 2.2 \\
\hline Germany & 39 & 39 & 0 & 10 \\
\hline Netherlands & 11 & 5 & 6 & 2.2 \\
\hline Sweden & 6 & 6 & 0 & 1.8 \\
\hline Total & 80 & 65 & 15 & - \\
\hline
\end{tabular}

${ }^{a}$ Date of testing was used when date of symptom onset was unavailable. 


\section{TABLE 3}

Sex and age of hepatitis A cases related to Egypt travel from Denmark, England, Germany, the Netherlands, Norway and Sweden with symptom onset date ${ }^{\mathrm{a}}$ after 01 November 2012 as of 24 April $2013(n=80)^{*}$

\begin{tabular}{|l|c|c|}
\hline $\begin{array}{l}\text { Country } \\
\text { of origin }\end{array}$ & $\begin{array}{c}\text { Median age } \\
\text { (range) }\end{array}$ & $\begin{array}{c}\text { Proportion } \\
\text { of males (\%) }\end{array}$ \\
\hline Denmark & $28(10-57)$ & $6 / 7(86)$ \\
\hline England & $30(4-56)$ & $4 / 11(36)$ \\
\hline Germany & $48(4-76)$ & $19 / 39(49)$ \\
\hline Netherlands & $38(21-59)$ & $3 / 11(27)$ \\
\hline Norway & $56(22-63)$ & $2 / 6(33)$ \\
\hline Sweden & $17(3-75)$ & $3 / 6(50)$ \\
\hline
\end{tabular}

a Date of testing was used when date of symptom onset was unavailable.
Interviews of Norwegian and Danish cases

In Norway, all six cases have been interviewed using a short questionnaire designed to collect information on clinical information, travel history and places of food consumption. Five cases travelled to Sharm-El-Sheik with the same travel company, but stayed in two different hotels; the sixth case travelled to Hurghada with a different company. Four of the cases have been hospitalised. In Denmark, five of seven cases have been interviewed using a similar questionnaire to that used in Norway. Three travelled to Sharm-El-Sheik with the same travel company and stayed at the same hotel. One case also travelled to Sharm-El-Sheik and stayed at a different hotel. One case travelled to Hurghada with a third company. All cases from Norway and Denmark stayed at hotels that were all-inclusive or had on-site restaurants, and all cases reported eating exclusively or almost exclusively from the hotel facilities. A multinational investigation on common exposures among the reported cases from all countries, including hotels, airlines, organised tours and food items, is currently being considered.

\section{FIGURE}

Distribution of probable and confirmed hepatitis A cases with travel history to Egypt, by country of origin and week of symptom onset after 01 November 2012 as of 24 April 2013

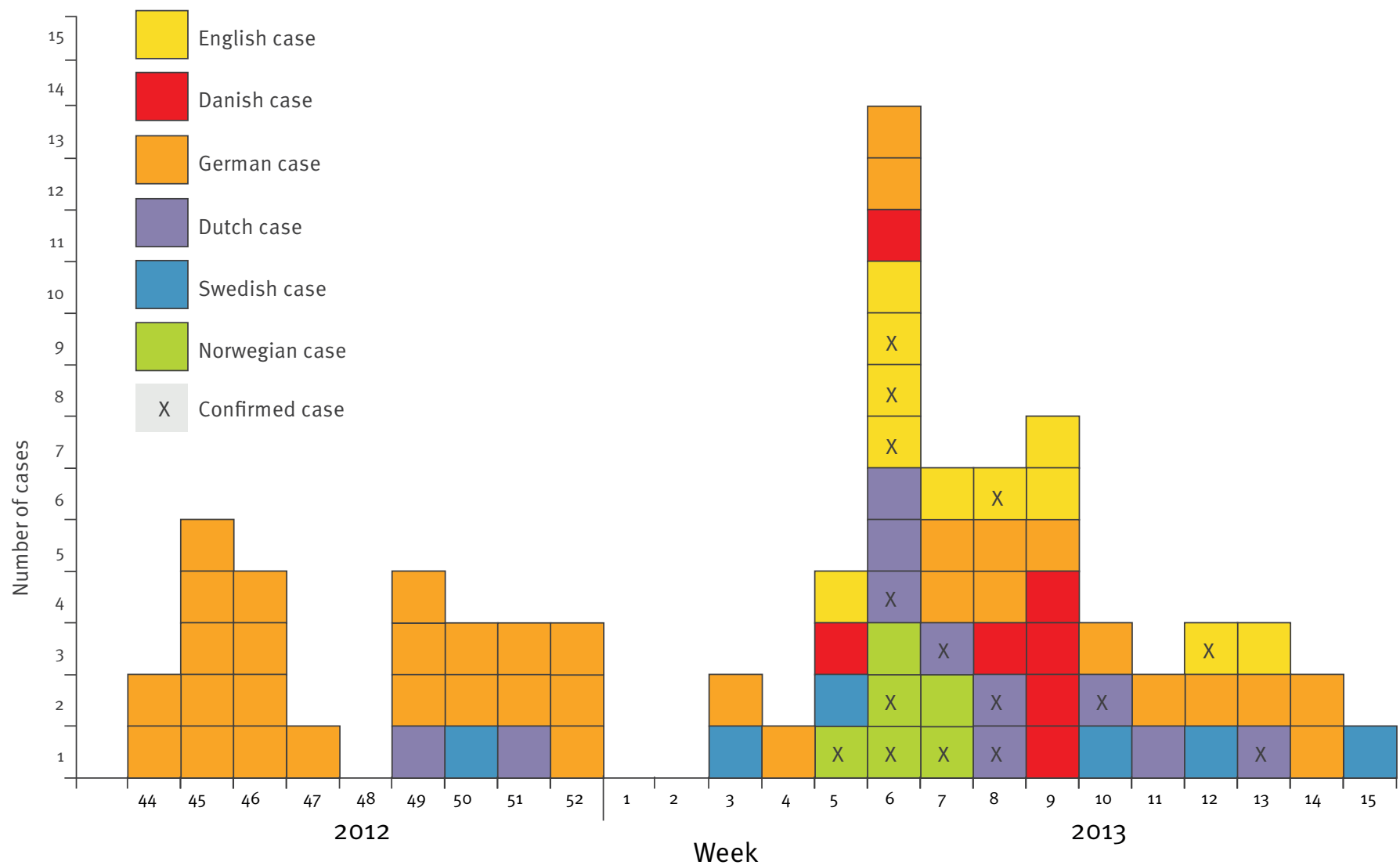

Only 78 of the total 80 cases are represented on the figure as symptom onset date was only available for 37 of 39 German cases. 
Location of travel in Egypt of total hepatitis A cases from Denmark, England, Germany, the Netherlands, Norway and Sweden with symptom onset date 01 November 2012 as of 24 April 2013 (n=80)

\begin{tabular}{|c|c|c|c|c|c|c|}
\hline \multirow[t]{2}{*}{ Country of origin } & \multicolumn{6}{|c|}{$\begin{array}{l}\text { Location of travel in Egypt } \\
\text { Number of cases (number of confirmed outbreak cases) }\end{array}$} \\
\hline & Sharm-El-Sheik & Hurghada & Marsa Alam & Cairo & Multiple locations & Unknown \\
\hline Denmark & $3(0)$ & $1(0)$ & o (o) & o (o) & $1(0)^{\mathrm{b}}$ & $2(0)$ \\
\hline England & $6(4)$ & $2(1)$ & o (o) & $1(0)$ & $1(0)^{c}$ & $1(0)$ \\
\hline Germany & $2(0)$ & $12(0)$ & $1(0)$ & $2(0)$ & $2(0)^{d}$ & $20(0)$ \\
\hline Netherlands & $2(0)$ & $3(3)$ & o (o) & o (o) & o (o) & $6(3)$ \\
\hline Norway & $5(4)$ & $1(0)$ & o (o) & $\mathrm{o}(0)$ & $\mathrm{o}(0)$ & $\mathrm{o}(\mathrm{o})$ \\
\hline Sweden & $2(0)$ & $1(0)$ & o (o) & o (o) & o (o) & $3(0)$ \\
\hline Total & $20(8)$ & $20(4)$ & $1(0)$ & $3(0)$ & $4(0)$ & $32(3)$ \\
\hline Percentage of all cases & 25 & 25 & 1 & 3 & 4 & 40 \\
\hline
\end{tabular}

a Date of testing was used when date of symptom onset was unavailable.

b The case went on a Nile cruise and to Sharm-El-Sheik.

The case took part in a Red Sea cruise and traveled to Sharm-El-Sheik.

One case participated in a Nile cruise, the other case went on a Nile Cruise, to Hurghada and to Cairo.

\section{Laboratory investigations}

The genome sequence ( $\mathrm{N}$-terminal $\mathrm{VP}_{1}$ and $\left.\mathrm{VP}_{1} / \mathrm{P}_{2} \mathrm{~A}\right)$ of HAV from four of the six Norwegian cases was identical (HAV genotype 1B); the remaining cases have not yet been sequenced. The outbreak sequence (provided at the end of the article), has been submitted to the Foodborne Viruses in Europe network (FBVE network), and is being submitted to Genbank. The Netherlands has acquired sequence data from six cases, of which all share an identical RNA sequence in the overlapping region of 440 nucleotides in the $\mathrm{VP}_{1} / \mathrm{P}_{2} \mathrm{~A}$ region with the outbreak strain. England has identified identical sequences to those reported by Norway in five laboratory-confirmed cases. Denmark and England have excluded two and four cases, respectively, based on genotyping, which are not presented here, including several $1 \mathrm{~B}$ HAV strains in cases with travel history to Egypt during the outbreak period. In Sweden and Germany, genotyping is being considered.

The Nordic countries, Germany, the Netherlands and England have relatively few cases of HAV reported annually. If an increase in cases is detected in several countries simultaneously, genotyping and sequencing potentially enables linking of cases internationally. However, many countries do not routinely type to this level, which may explain why so few countries have reported an increase following the messages sent through EPIS and EWRS. The response from specific countries in this outbreak may also have been attributable to the heightened awareness due to the concurrent outbreak of HAV in Nordic countries [13]. The initial response from the represented countries may also reflect travel patterns in people from colder climates during the winter months.

\section{Vaccination recommendations}

Despite the explicit vaccination recommendations in all involved countries for travellers to Egypt, almost no cases were vaccinated prior to travel. In Denmark, England, the Netherlands, Norway and Sweden all cases with known vaccination status were unvaccinated. In Germany one case reported full course of vaccination and is being interpreted as a vaccination failure. All other cases from Germany with available information were unvaccinated. This increase in cases reported from European travellers returning from Egypt suggests that European public health authorities should consider reinforcing HAV vaccine recommendations for tourists travelling to endemic areas, especially Egypt. Although HAV vaccination is recommended, with the exception of England, none of the involved countries fund the vaccination of tourists or include the vaccine as part of the national vaccination plan. In England the hepatitis A vaccine is often provided free of charge by general practitioners.

The lack of vaccination may be partly explained by the perception among travellers that the risk of acquiring hepatitis $A$ is low when engaging in organised holidays or activities. All interviewed cases in Norway and Denmark stayed in hotels that were either all-inclusive or had restaurants on-site. Information regarding participation of HAV cases in specific activities such as cruises, day trips, organised tours and recreational activities that may present a risk of exposure is unavailable at this time. Public health authorities may wish to engage travel companies in order to ensure travellers are informed about vaccination requirements prior to travel. Because of the increasing number of travellers booking tickets online, an automated reminder 
when booking tickets has also been suggested as a means of increasing vaccination coverage [14]. Further investigation into the level of knowledge and attitudes among tourists visiting countries where hepatitis $A$ is prevalent, particularly those joining chartered tours, could assist in targeting information about HAV vaccination. The collection of this information is being planned as part of the next stage of the multi-national investigation.

\section{Conclusions}

This investigation into an outbreak of cases of hepatitis A in tourists to Egypt from several EU/EEA countries is ongoing and at this time the dynamics of the increase in cases are unclear. Although the background level in Egypt of the HAV strain involved in this outbreak is unknown at this time, a unique sequence among cases may indicate a common exposure. This hypothesis is potentially reinforced as confirmed cases appear to be temporally clustered between Week 5 and Week 10 of 2013. As of 25 April 2013 a total of 13 countries have responded to the EPIS urgent inquiry that they have at least one case which may match the probable case definition and are being investigated. The authors would like to invite other countries that have experienced an increase in hepatitis A in tourists returning from Egypt, or that have detected the sequences reported here, to share their data with the outbreak team. The National Institute for Public Health and the Environment in the Netherlands (RIVM) and Norwegian Institute of Public Health (depending on capacity) offer their sequence facilities to countries where sequencing is not among routine procedures. Please be aware that an actual rise may only be noted through typing. Sequences can be shared and compared in an international HAV database prepared by RIVM, for which access can be obtained by contacting fbve@rivm.nl.

\section{Acknowledgements}

We would like to thank Heidi Lange and Fredrik Andersen at the Norwegian Institute of Public Health for interviewing cases. Thank you to Alicia Barrasa from the EPIET programme for reviewing the manuscript. Thank you to Céline Gossner and Ettore Severi at the European Centre for Disease Prevention and Control for their input in developing the manuscript. We would also like to thank Michael Edelstein from Swedish Institute of Communicable Disease Control for providing data.

\section{Authors' contribution}

EM contributed to the descriptive study in Norway, gath ered information from other countries and and drafted the manuscript as the lead writer. MF, CF and MG contributed with data from Germany and commented on the manuscript. SGL conducted the descriptive study in Denmark and commented on the manuscript, SEM contributed to the laboratory sequencing and analysis for Denmark and commented on the manuscript, LS contributed with data from Sweden and commented on the manuscript, AS and LVo contributed with data on the Norwegian cases and commented on the manuscript. LVo posted the initial message in EPIS for Norway, gathered data from the different countries and took initiative to writing up the Eurosurveillance rapid communication. $\mathrm{KS}$ ) contributed to the laboratory sequencing and analysis for Norway and commented on the manuscript. MK, WvP, JS and LVe all contributed with data from the Netherlands and commented on the manuscript. SLN carried out the genotyping and sequencing of the cases from England and JL JC and KB contributed to collating epidemiological data and all commented on the manuscript.

Outbreak sequence information

NOR-2013-V9-Egypt_VP1/2PA:

CAATCACTCTGATG A ATATTTGTCTTTTAGTTG CTA TTTGTCTGTCACAGAACAATCAGAGTTTTATTTTCC CAGAGCTCCATTGAATTCAAATGCCATGTTATCCAC TGAATCAATGATGAGCAGAATTGCAGCTGGAGACT TGGAGTCATCAGTGGATGATCCTAGATCAGAGGAG GACA A A A G ATT TGAGAGTCACATAGAATGCAGGAA GCCATATAAAGAATTGAGATTAGAAGTTGGGAAAC AAAGACTTAAGTATGCTCAGGAAGAATTGTCAAATG A A G TACTTCCACCCCCTAGGAAAATTAAAGGACTG T TTTCACAAGCCAAAATTTCTCTTTTTTATACTGAGGAG CATGAAATAATGAAATTTTCTTGGAGAGGAGTGACT GCTGATACTAGAGCTTTAAGGAGGTTTGGATTC TC T T TG G C T G C T G G G

NOR-2013-V9-Egypt_VP1:

GATG TCACCACACAGGTTGGAGATGATTCTGGAGGT TTTTCAACGACAGTTTCTACAGAGCAGAATGTTCCAG ATCCACAAGTTGGCATAACAACCATGAAGGATTTAAA GGGAAAAGCCAACAGAGGGAAAATGGATGTTTCAG GAGTGCAAGCACCTGTGGGAGCTATTACAACAATTGA GGATCCAGTTTTAGCAAAGAAAGTACCTGAGACATTT CCTGAATTGAAACCTGGAGAATCCAGGCACACATCAG ATCATATGTCCATTTACAAGTTTATGGGAAGGTCTCAC TTTTTGTGCACTTTTACTTTCAATTCAAACAATAAAGAA TACACATTTCCTATAACCTTGTCTTCAACCTCCAATCCTC CTCATGGTTTGCCATCTACATTGAGGTGGTTTTTCAACT TGTTTCAGTTGTATAGAGGACCTTTGGATCTAACAATT ATAATTACAGGAGCAA

\section{Conflict of interest}

None declared.

*Authors' correction:

The value of $46 \%$ in the sentence 'Overall, $46 \%$ of cases are male, and the ages of cases range from three to 76 years (Table 3)' was erroneously written as $49 \%$ in the original publication. In addition in Table 3, for England, the values of $4 / 11$ for the proportion of males, and 36 for the respective percentage were originally $7 / 11$ and 64 . These mistakes were corrected on 26 April 2013. 


\section{References}

1. European Centre for Disease Prevention and Control (ECDC). Annual epidemiological report. Reporting on 2010 surveillance data and 2011 epidemic intelligence data 2012. Stockholm: ECDC. Available from: http://www.ecdc.europa. eu/en/publications/Publications/Annual-EpidemiologicalReport-2012.pdf

2. Payne L, Coulombier D. Hepatitis A in the European Union: responding to challenges related to new epidemiological patterns. Euro Surveill. 2009;14(3):pii=19101. Available from: http://www.eurosurveillance.org/ViewArticle. aspx?Articleld $=19101$

3. Frank C, Walter J, Muehlen M, Jansen A, van Treeck U, Hauri AM, et al. Major Outbreak of Hepatitis A Associated with Orange Juice among Tourists, Egypt, 2004. Emerg Infect Dis. 2007;13(1):156-8 http://dx.doi.org/10.3201/eid1301.060487 PMid:17370535 PMCid:2725821

4. Robesyn E, Micalessi MI, Quoilin S, Naranjo M, Thomas I. Cluster of hepatitis A cases among travellers returning from Egypt, Belgium, September through November 2008. Euro Surveill. 2009;14(3):pii=19095. Available from: http://www. eurosurveillance.org/ViewArticle.aspx?Articleld=19095

5. Couturier E, Roque-Afonso AM, Letort MJ, Dussaix E, Vaillant $\mathrm{V}$, de Valk H. Cluster of cases of hepatitis A with a travel history to Egypt, September - November 2008, France. Euro Surveill. 2009;14(3):pii=19094. Available from: http://www. eurosurveillance.org/ViewArticle.aspx?Articleld=19094

6. Bernard H, Frank C. Cluster of hepatitis A cases among travellers returning from Egypt, Germany, September through November 2008. Euro Surveill. 2009;14(3):pii=19096. Available from: http://www.eurosurveillance.org/ViewArticle. aspx?Articleld $=19096$ PMid:19161724

7. Kamel AH, Ali MA, El-Nady HG, Deraz A, Aho S, Pothier P, et al. Presence of enteric hepatitis virus in the sewage and population of Greater Cairo. Clin Microbiol Infect. 2011;17(8): 1182-5. http://dx.doi.org/10.1111/j.1469-0691.2011.03461 PMid:21375654

8. The Office for National Statistics. International Passenger Survey 2008 to 2012. UK Crown copyright 2009-2013.

9. German National Statistics Office (DESTATIS). Air traffic - Series 8, Periodical 6, regarding March 2012 through February 2013. Wiesbaden: DESTATIS; 2012. German. Available from: http://www.ons.gov.uk/ons/guide-method/surveys/ respondents/household/international-passenger-survey/ index.html

10. Central Bureau of Statistics, Netherlands. Available from: http://www.cbs.nl/nl-NL/menu/home/default.htm

11. Norwegian Tourism In Egypt. Norway - The Official Site in Egypt. [Accessed 25 Apr 2013]. Available from: http:// www.norway-egypt.org/aboutnorway/NorwaylnEgypt/ Norwegian Tourism in Egypt/

12. Swedish Travel and Tourist database. Available from: http:// www.resursab.se/

13. Joint ECDC-EFSA Rapid Outbreak Assessment - Outbreak of hepatitis A virus infection in four Nordic countries. Stockholm: European Centre for Disease Prevention and Control (ECDC). Available from: http://ecdc.europa.eu/en/publications/ Publications/hepatitis-a-rapid-assessment-nordic-countriesapril2013.pdf

14. Ward M, Borgen K, Mazick A, Muehlen M. Hepatitis A vaccination policy for travellers to Egypt in eight European countries, 2004. Euro Surveill. 2006;11(1):pii=592. Available from: http://www.eurosurveillance.org/ViewArticle. aspx?Articleld $=592$ 